\title{
KOMPARASI PETA KURVA RESIDU SISTEM TERNER ASETON-n-BUTANOL-ETANOL DENGAN METANOL-ETANOL-PROPANOL
}

\author{
N. K. Sari, Kuswandi, N. Soewarno dan R. Handogo ${ }^{*}$
}

\begin{abstract}
Abstrak
Simulasi pemisahan sistem terner Metanol-Etanol-1-Propanol (MEP) pada tekanan atmosfer menggunakan distilasi batch sederhana telah diteliti. Peta kurva residu kemudian dibuat untuk dilihat apakah sistem tersebut mempunyai campuran azeotropik atau campuran zeotropik. Peta kurva residu dari sistem terner MEP tersebut dibandingkan pula dengan peta kurva residu dari sistem terner Aseton-n-Butanol-Etanol. Untuk menghitung tekanan uap jenuh digunakan persamaan Antoine berdasarkan kondisi atmosferik. Koefisien aktivitas dihitung menggunakan persamaan UNIQUAC. Forward-finite-difference digunakan untuk menghitung komposisi dibagian bawah kolom pada waktu yang ditentukan dari komposisi awal MEP. Beberapa nilai-nilai awal komposisi MEP yang telah dipilih untuk melengkapi peta kurva residu dengan simulasi menggunakan bahasa MathLab versi 6.1. Hasil menunjukkan bahwa secara simulasi sistem terner MEP adalah campuran zeotropik, tanpa mempunyai campuran azeotropik biner dari masing-masing komponennya. Peta kurva residu sistem terner MEP kemudian dibandingkan dengan literatur dan divalidasi secara hubungan topologi antara jumlah noda tidak stabil, jumlah noda stabil dan jumlah sadel.
\end{abstract}

Kata kunci: Azeotropik, distilasi batch, sistem terner, peta kurva residu, zeotropik.

\section{Pendahuluan}

Pada awalnya distilasi batch sederhana digunakan untuk memisahkan sistem biner yaitu sistem $\mathrm{HCl}-\mathrm{H}_{2} \mathrm{O}, \quad \mathrm{H}_{2} \mathrm{SO}_{4}-\mathrm{H}_{2} \mathrm{O}, \quad \mathrm{NH}_{3}-\mathrm{H}_{2} \mathrm{O}$, Rayleigh (1902). Setelah itu dikembangkan untuk pemisahan sistem terner, salah satu contoh pemisahan MEP untuk memperoleh komponen murni dari masing-masing komponen.

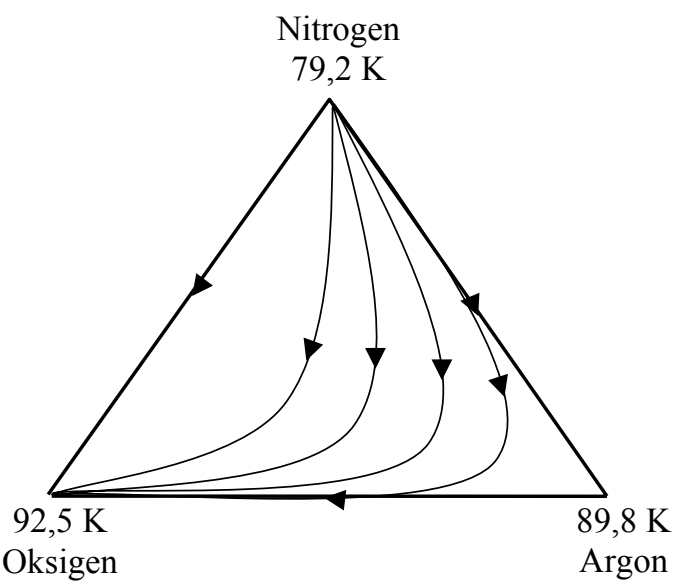

Gambar 1. Peta kurva residu nitrogen-argon-oksigen, Stichlmair dkk. (1989).

Dari peta kurva residu dapat dilihat apakah campuran terner tersebut membentuk campuran zeotropik, campuran homogen azeotropik dan campuran heterogen azeotropik. Gambar 1 menunjukkan peta kurva residu sistem terner nitrogen-argon-oksigen yang membentuk campuran zeotropik, pergerakan komposisi liquida menuju arah oksigen dan awal pergerakan dimulai dari nitrogen. Pemisahan campuran tersebut tidak bisa menghasilkan argon murni karena argon mempunyai titik didih sedang dan membentuk aliran sadel, dan bisa menghasilkan nitrogen dan oksigen murni karena nitrogen membentuk aliran noda tidak stabil dan oksigen membentuk aliran noda stabil.

Octane

$396,8 \mathrm{~K}$

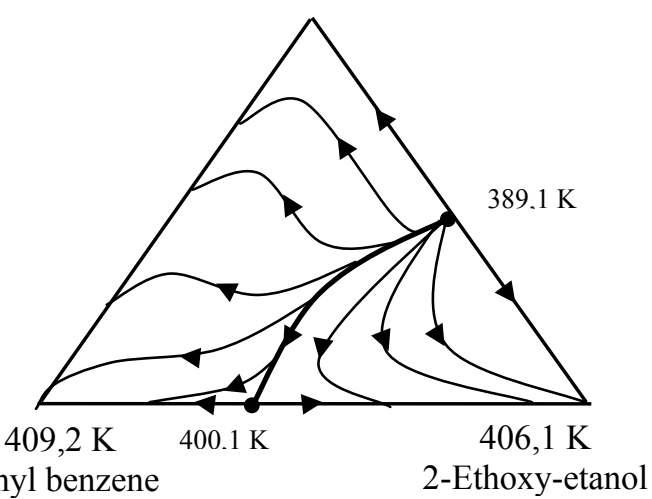

Gambar 2. Peta kurva residu octane-2-ethoxyethanolethyl benzene, Stichlmair dkk. (1989).

\footnotetext{
${ }^{*}$ Jurusan Teknik Kimia FTI-ITS

Kampus ITS Keputih Sukolilo -Surabaya 60111, Indonesia

Telp. (031) 5946240. Fax. (031) 5999282.
} 
Gambar 2 menunjukkan peta kurva residu sistem terner octane-2 ethoxyetanol-ethylbenzene yang membentuk dua buah sistem biner azeotropik homogen minimum dan dipisahkan oleh satu boundary distillation. Melihat arah pergerakan masing-masing komponen tidak bisa dihasilkan octane murni, karena octane membentuk aliran sadel, sedangkan 2 ethoxy-etanol dan ethylbenzene bisa menghasilkan komponen murni karena masing-masing membentuk aliran noda stabil.

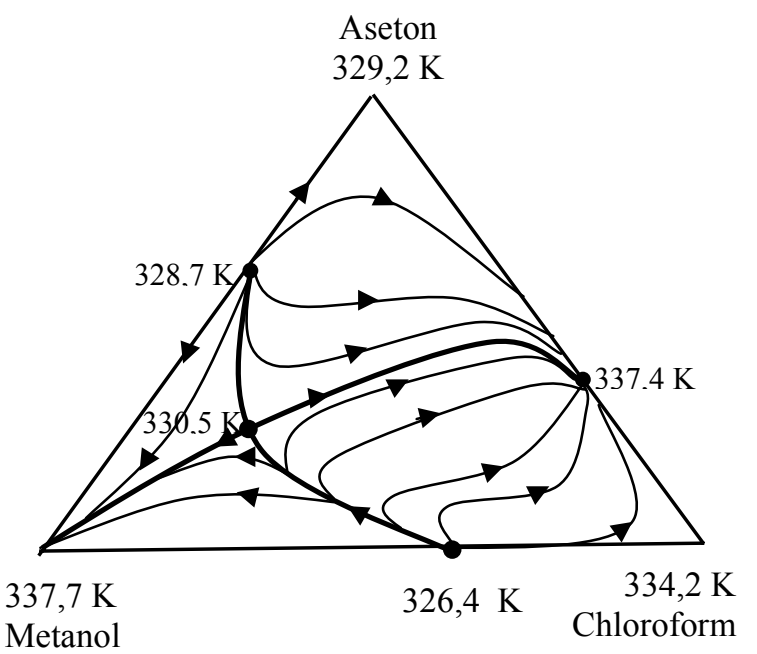

Gambar 3. Peta kurva residu aseton-chloroformmetanol, Stichlmair dkk. (1989).

Gambar 3 menunjukkan peta kurva residu sistem terner aseton-chloroform-metanol membentuk dua buah sistem biner azeotropik minimum dan satu buah sistem biner azeotropik maksimum, satu buah sistem terner azeotropik heterogen, dibatasi oleh dua buah boundary distillation. Melihat arah pergerakan dari masingmasing komponen, untuk metanol bisa menghasilkan komponen murni, karena metanol membentuk aliran noda stabil, sedangkan aseton dan chloroform tidak bisa membentuk komponen murni, karena aseton dan chloroform masing-masing membentuk aliran sadel. Gambar 1 sampai Gambar 3 kemudian ditulis ulang oleh Soemantri dkk. (1996) dalam bentuk journal review.

Espinosa dan Salomone (1999) melakukan penelitian distilasi batch sederhana pada campuran ideal dan nonideal, kemudian untuk analisa hasil dibuat dalam peta kurva residu. Dalam penelitian yang dilakukan menggunakan persamaan Underwood, dimana kelebihan dari penelitian ini dapat diaplikasikan pada rektifikasi batch dan campuran yang sangat tidak ideal yaitu campuran aseton-metanol-etanol.

Selain itu peta kurva residu juga bisa dipakai untuk memprediksi apakah sistem terner tersebut membentuk campuran azeotropik atau campuran zeotropik, dilihat dari kesetimbangan uap dan cair. Sistem terner yang diteliti adalah acetone-air-MEK, dalam menghitung kesetimbangan uap dan cair menggunakan persamaan NRTL. Penyelesaian model persamaan distilasi batch sederhana menggunakan
Aspen Plus dan DISTIL. Dilihat dari peta kurva residu bahwa campuran acetone-air-MEK membentuk campuran azeotropik heterogen, dilihat dari komposisi liquida di residu berada dalam kurva VL(L)E. (Villiers dkk. 2002).

Egbewatt dan Fletcher (2003) melakukan simulasi dan eksperimen campuran terner isopropanol-methylcyclohexane-toluene, untuk simulasi menggunakan model yang ditulis oleh Doherty dan Perkins (1978) dengan metoda RungeKutta prediksi kesetimbangan uap-liquid menggunakan UNIFAC serta data diambil dari Gmehling dan Onken (1977) dan penyelesaian modelnya menggunakan bahasa Fortran. Dari hasil simulasi dan eksperimen sistem terner isopropanolmethylcyclohexane-toluene, dilihat dari peta kurva residu membentuk campuran azeotropik heterogen.

Simulasi pemisahan sistem terner ABE pada tekanan atmospir menggunakan distilasi batch sederhana telah diteliti, hasil penelitian dalam bentuk peta kurva residu membentuk campuran zeotropik tanpa campuran sistem biner azeotropik dari masingmasing komponen binernya. Untuk validasi listing program simulasi pemisahan sistem terner $\mathrm{ABE}$ digunakan sistem terner zeotropik yaitu sistem terner MEP.

Persamaan yang berlaku untuk pemisahan sistem terner distilasi batch sederhana (Henley dan Seader, 1998), dapat dijabarkan dari pengurangan kecepatan aliran dalam still pot $\left(\mathrm{V}_{\mathrm{m}}\right)$ dan kecepatan aliran keluar $\left(\mathrm{V}_{1}\right)$ :

$$
\begin{gathered}
\mathrm{V}_{\mathrm{m}}=-\mathrm{d} / \mathrm{dt}\left(\mathrm{W} \cdot \mathrm{x}_{\mathrm{W}}\right) \\
\mathrm{V}_{\mathrm{m}}=-\mathrm{W} \cdot \mathrm{dx}_{\mathrm{W}} / \mathrm{dt}-\mathrm{x}_{\mathrm{W}} \cdot \mathrm{dW} / \mathrm{dt} \\
\mathrm{V}_{\mathrm{l}}=\mathrm{D} \cdot \mathrm{y}_{\mathrm{D}}
\end{gathered}
$$

Pengurangan kecepatan aliran dalam kolom = kecepatan aliran keluar

$$
\begin{gathered}
W \cdot d x_{W} / d t+x_{W} \cdot d W / d t=-D \cdot y_{D} \\
\frac{d x_{w}}{d t}=\left(y_{D}-x_{W}\right) \frac{d W}{W d t}
\end{gathered}
$$

Dalam pemisahan sistem terner, diasumsikan bahwa liquida bercampur sempurna, dimana $\mathrm{x}_{\mathrm{w}}=\mathrm{x}_{\mathrm{i}}$ dan $\mathrm{y}_{\mathrm{D}}$ $=\mathrm{y}_{\mathrm{i}}$ maka Persamaan (3) ditulis berikut :

$$
\frac{\mathrm{dx}_{\mathrm{i}}}{\mathrm{dt}}=\left(\mathrm{y}_{\mathrm{i}}-\mathrm{x}_{\mathrm{i}}\right) \frac{\mathrm{dW}}{\mathrm{Wdt}}
$$

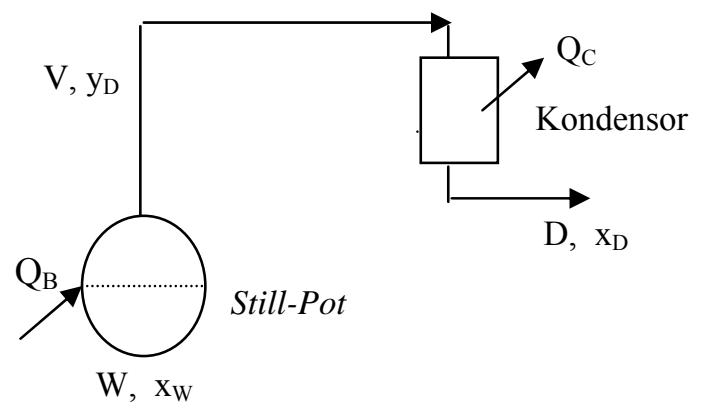

Gambar 4. Sketsa aliran distilasi batch sederhana 
Model Differential-Algebraic-Equations (DAEs) untuk distilasi batch sederhana sistem terner, asumsi tidak membentuk dua phase liquida ditulis berikut :

$$
\mathrm{d} \xi=\frac{-\mathrm{dx}_{\mathrm{i}}}{\left(\mathrm{x}_{\mathrm{i}}-\mathrm{y}_{\mathrm{i}}\right)}
$$

Dari Persamaan (4) dan (5) maka diperoleh :

$$
\frac{\mathrm{d} \xi}{\mathrm{dt}}=-\frac{1}{\mathrm{~W}} \frac{\mathrm{dW}}{\mathrm{dt}}
$$

Dengan initial condition : $\mathrm{t}=0$ dan $\mathrm{W}=\mathrm{W}_{\mathrm{o}}$, maka Persamaan (6) untuk dimensionless waktu $(\xi)$ berikut :

$$
\begin{aligned}
& \xi(\mathrm{t})=\ln \frac{\mathrm{Wo}}{\mathrm{Wt}} \\
& \mathrm{D}(\mathrm{t})=\mathrm{Wo}-\mathrm{W}(\mathrm{t})
\end{aligned}
$$

Menurut Doherty dan Perkins (1978), maka Persamaan (5) menjadi :

$$
\begin{array}{r}
\frac{\mathrm{dx}_{\mathrm{i}}}{\mathrm{d} \xi}=\left(\mathrm{x}_{\mathrm{i}}-\mathrm{y}_{\mathrm{i}}\right) \\
\mathrm{y}_{\mathrm{i}}=\mathrm{K}_{\mathrm{i}} \mathrm{x}_{\mathrm{i}} \quad \mathrm{i}=1,2,3
\end{array}
$$

Nilai konstanta kesetimbangan $\left(\mathrm{K}_{\mathrm{i}}\right)$ dihitung dengan modifikasi hukum Raoult.

$$
\begin{gathered}
\mathrm{K}_{\mathrm{i}}=\frac{\gamma_{\mathrm{i}} \mathrm{P}_{\mathrm{i}}^{\mathrm{S}}}{\mathrm{P}} \\
\ln \mathrm{P}_{\mathrm{i}}^{\mathrm{S}}=\mathrm{A}_{\mathrm{i}}-\frac{\mathrm{B}_{\mathrm{i}}}{\mathrm{C}_{\mathrm{i}}+\mathrm{T}}
\end{gathered}
$$

Dengan forward-finite-difference, maka komposisi liquida $\left(\mathrm{x}_{\mathrm{i}, \mathrm{j}+1}\right)$ fungsi $\Delta \xi$ dapat ditulis sebagai berikut

$$
\left(\mathrm{x}_{\mathrm{i}, \mathrm{j}+1}-\mathrm{x}_{\mathrm{i}, \mathrm{j}}\right) / \Delta \xi=\mathrm{x}_{\mathrm{i}, \mathrm{j}}-\mathrm{y}_{\mathrm{i}, \mathrm{j}}
$$

Komposisi liquida mula-mula $\left(\mathrm{x}_{\mathrm{i}, \mathrm{j}}\right)$ ditentukan, sedangkan untuk menghitung komposisi uap $\left(\mathrm{y}_{\mathrm{i}, \mathrm{j}}\right)$ menggunakan temperatur bubble.

Untuk validasi hasil simulasi sistem terner MEP secara hubungan topologi yang telah digambar dalam bentuk peta kurva residu menggunakan persamaan pada literatur Henley dan Seader (1998) berikut :

$$
\begin{gathered}
\mathrm{N}_{1}+\mathrm{S}_{1}=3 \\
\mathrm{~N}_{2}+\mathrm{S}_{2}=\mathrm{B} \leq 3 \\
\mathrm{~N}_{3}+\mathrm{S}_{3}=1 \text { atau } 0
\end{gathered}
$$

Menurut Doherty dan Perkins (1979) dikembangkan hubungan secara topologi antara $\mathrm{N}$ dan $\mathrm{S}$ berikut :

$$
2 \mathrm{~N}_{3}-2 \mathrm{~S}_{3}+2 \mathrm{~N}_{2}-\mathrm{B}+\mathrm{N}_{1}=2
$$

dengan $\mathrm{N}_{1}$ merupakan jumlah noda stabil atau noda tidak stabil, $\mathrm{S}_{1}$ merupakan jumlah sadel. Untuk menentukan jumlah noda stabil, noda tidak stabil dan sadel ditentukan dari pola aliran seperti pada literatur Henley dan Seader (1998). $\mathrm{N}_{2}$ merupakan jumlah noda stabil dan noda tidak stabil biner azeotropik, $\mathrm{S}_{2}$ merupakan jumlah sadel biner azeotropik. $\mathrm{N}_{3}$ merupakan jumlah noda stabil dan noda tidak stabil terner azeotropik, $\mathrm{S}_{3}$ merupakan jumlah sadel terner azeotropik. B merupakan biner azeotropik, apabila Persamaan (14) sampai (17) terpenuhi, maka simulasi bisa diterima (memenuhi syarat).

\section{Metode Penelitian}

Penyelesaian model DAEs dengan metoda Euler menggunakan program Mathlab versi 6.1. Dalam menentukan komposisi umpan sistem terner ABE dilakukan secara acak kurang lebih 24 Run. Untuk memudahkan dalam membuat peta kurva residu, diambil 7 Run saja agar kurva tidak saling berhimpit, dengan komposisi liquida sistem terner ABE seperti Tabel 1.

Tabel 1. Komposisi liquida sistem terner ABE

\begin{tabular}{|c|c|c|c|}
\hline \multirow{2}{*}{ No } & \multicolumn{3}{|c|}{ Komposisi Umpan (fraksi mol) } \\
\cline { 2 - 4 } & Aseton & n-Butanol & Etanol \\
\hline 1 & 0.8 & 0.1 & 0.1 \\
2 & 0.7 & 0.2 & 0.1 \\
3 & 0.7 & 0.1 & 0.2 \\
4 & 0.6 & 0.3 & 0.1 \\
5 & 0.6 & 0.1 & 0.3 \\
6 & 0.5 & 0.1 & 0.4 \\
7 & 0.4 & 0.1 & 0.5 \\
\hline
\end{tabular}

Penentuan komposisi umpan sistem terner MEP berdasarkan data yang sudah ada pada literatur (Henley dan Seader, 1998), seperti Tabel 2.

Tabel 2. Komposisi liquida sistem terner MEP

\begin{tabular}{|c|c|c|c|}
\hline & \multicolumn{3}{|c|}{ Komposisi Umpan (fraksi mol) } \\
\hline No & Metanol & Etanol & 1-Propanol \\
\hline 1 & 0.80 & 0.10 & 0.10 \\
\hline 2 & 0.90 & 0.02 & 0.08 \\
\hline 3 & 0.70 & 0.20 & 0.10 \\
\hline 4 & 0.30 & 0.60 & 0.10 \\
\hline 5 & 0.39 & 0.60 & 0.01 \\
\hline 6 & 0.50 & 0.40 & 0.10 \\
\hline
\end{tabular}

Untuk menghitung tekanan uap jenuh masing-masing komponen digunakan persamaan Antoine, data parameter Antoine seperti Tabel 3 (Prausnitz, 2001), dimana suhu (T) dalam satuan $\mathrm{K}$ dan tekanan uap jenuh $\left(\mathrm{P}^{\text {sat }}\right)$ dalam satuan Bar.

Tabel 3. Parameter Antoine sistem terner ABE

\begin{tabular}{|l|c|c|c|}
\hline \multirow{2}{*}{ Komponen } & \multicolumn{3}{|c|}{ Parameter Antoine (Bar.) } \\
\cline { 2 - 4 } & $\mathrm{A}$ & $\mathrm{B}$ & $\mathrm{C}$ \\
\hline Aseton & 4.2184 & 4.6493 & 5.3365 \\
Metanol & 5.20277 & 1580.08 & 239.500 \\
Etanol & 228.06 & 182.739 & 230.918 \\
1-propanol & 4.99991 & 1512.94 & 205.807 \\
n-Butanol & 1197.01 & 1395.14 & 1648.22 \\
\hline
\end{tabular}

Untuk menghitung koefisien aktivitas $(\gamma)$ campuran ABE digunakan persamaan UNIQUAC, dimana harga parameter interaksi biner UNIQUAC $\left(\mathrm{u}_{\mathrm{ij}}\right)$, data volume molekuler (r) dan luas permukaan molekuler (q) seperti Tabel 4 (Gmehling dan Onken, 1977), harga $\mathrm{z}=10$. 
Tabel 4. Parameter UNIQUAC sistem terner ABE

\begin{tabular}{|l|c|c|c|c|c|}
\hline Oomponen & Aseton & Butanol & Etanol & $\mathrm{r}$ & $\mathrm{q}$ \\
\hline Aseton & 0 & 198.659 & 98.752 & 2.5735 & 2.3359 \\
n-Butanol & 453.669 & 0 & 38.707 & 3.4542 & 3.0520 \\
Etanol & 94.242 & 75.355 & 0 & 2.1054 & 1.9720 \\
\hline
\end{tabular}

Untuk campuran MEP harga parameter interaksi biner UNIQUAC $\left(\mathrm{u}_{\mathrm{ij}}\right)$ (Hysys versi 3.1), data volume molekuler (r) dan luas permukaan molekuler (q), seperti Tabel 5 (Prausnitz, 2001).

\section{Tabel 5. Parameter UNIQUAC sistem terner MEP}

\begin{tabular}{|l|c|c|c|c|c|}
\hline Komp. & Metanol & Etanol & propanol & $\mathrm{r}$ & $\mathrm{q}$ \\
\hline Metanol & 0 & 482.309 & 181.163 & 1.4311 & 1.432 \\
Etanol & 791.834 & 0 & 71.759 & 2.1054 & 1.972 \\
1-propanol & -82.941 & -35.282 & 0 & 3.2499 & 3.128 \\
\hline
\end{tabular}

\section{Hasil dan Pembahasan}

Data hasil simulai sistem terner MEP setelah digambar dalam peta kurva residu membentuk campuran zeotropik, secara umum sistem terner segolongan misalnya seperti golongan alkohol (MEP), gas biner $\left(\mathrm{O}_{2}, \mathrm{~N}_{2}, \mathrm{Ar}_{2}\right)$ membentuk campuran zeotropik, terkecuali pada sistem terner ABE dimana sistem terner ABE terdiri dari golongan alkohol dan alkanon. Profil temperatur ABE dan MEP dari hasil simulasi yang digunakan adalah profil temperatur di bottom dan di distilat dengan menjumlahkan kedua temperatur kemudian dibagi dua.

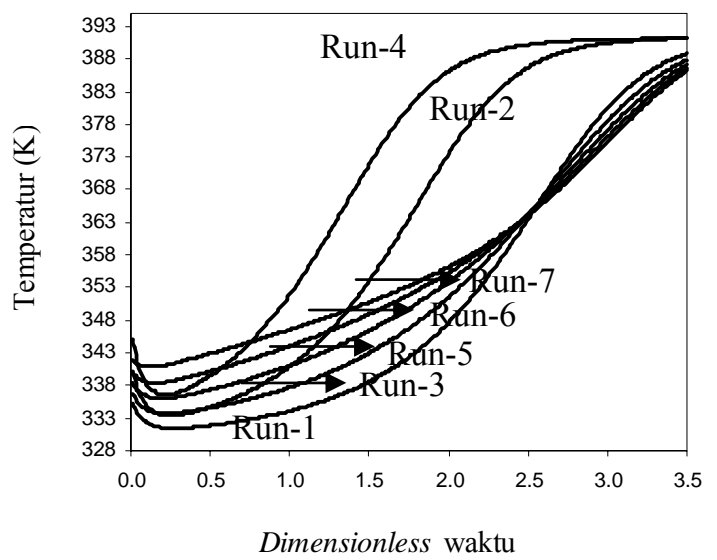

Gambar 5. Profil temperatur ABE, Run-1 sampai Run-7

Gambar 5 menunjukkan profil temperatur ABE makin naik, walaupun terjadi penurunan pada saat dimensionless waktu antara 0 sampai 0,25. Karena campuran ABE merupakan campuran antara golongan alkohol dan alkanon, dimana n-butanol mempunyai sifat sangat non ideal, sehingga mempengaruhi profil temperatur pada saat awal. Semakin besar komposisi nbutanol pada umpan masuk, maka slope penurunan suhu makin besar seperti yang ditunjukkan pada Run-2 dan Run-4.

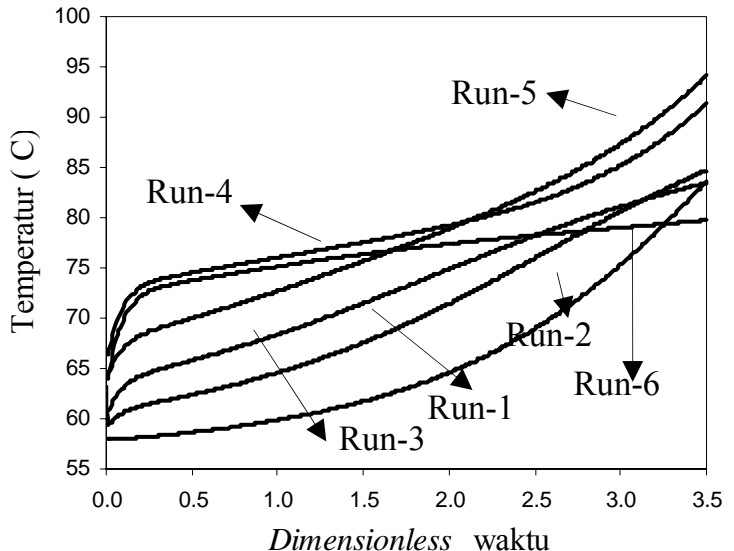

Gambar 6. Profil temperatur MEP, Run-1 sampai Run-7

Gambar 6 menunjukkan profil temperatur MEP makin naik untuk run-1 sampai run-6, secara umum yang diuapkan adalah semua komponen dengan komponen volatile diuapkan dalam porsi yang lebih besar. Dengan bertambahnya dimensionless waktu, komponen non-volatile dalam porsi yang lebih besar belum teruapkan di dalam bottom, sehingga dibutuhkan temperatur yang lebih besar untuk menguapkan komponen non-volatile yang belum diuapkan.

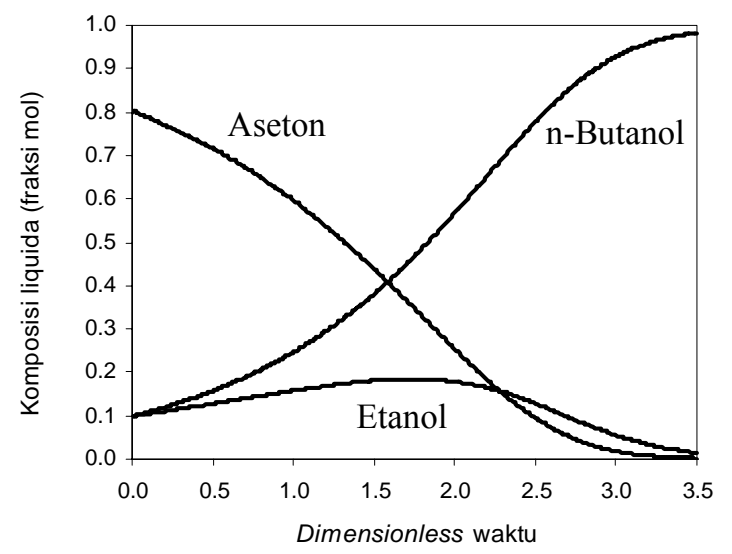

Gambar 7.Profil komposisi liquida ABE untuk Run-1

Gambar 7 menunjukkan profil komposisi liquida ABE untuk Run-1. Untuk dimensionless waktu antara 0 sampai 0,25 dimana profil komposisi aseton menurun, sedangkan n-butanol dan etanol naik. Slope komposisi butanol lebih besar dibandingkan komposisi etanol, karena komponen volatile (aseton) diuapkan dalam porsi yang lebih besar. Untuk dimensionless waktu antara 1,5 sampai 2 dimana profil komposisi etanol konstan, karena temperatur ABE mendekati titik didih etanol sehingga komposisi etanol konstan. Untuk dimensionless waktu antara 2 sampai 3,5 dimana profil komposisi etanol turun, karena temperatur ABE diatas titik didih etanol, sehingga komposisi etanol menguap dalam porsi kecil. Saat dimensionless 
waktu sama dengan 3 semua komponen volatile menguap dan saat dimensionless waktu sama dengan 3,5 temperatur campuran ABE mendekati titik didih butanol dan komposisi butanol mendekati murni.

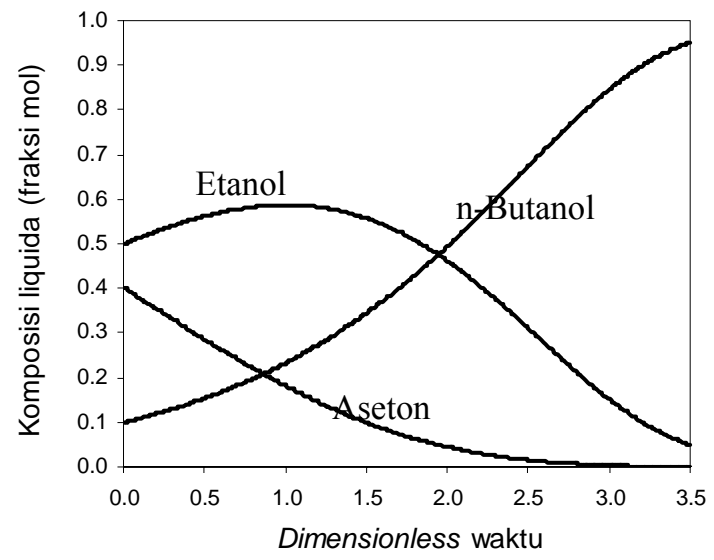

Gambar 8. Profil komposisi liquida ABE untuk Run-7.

Gambar 8 menunjukkan profil yang sama untuk komponen aseton dimana pada saat dimensionless waktu sama dengan 2,5 semua aseton sudah menjadi produk distilat. Tetapi untuk komponen butanol menunjukkan hasil yang sebaliknya, pada saat dimensionless waktu sama dengan 3,5 maka komposisi butanol menunjukkan nilai 0,96 sehingga dibutuhkan dimensionless waktu yang lebih besar untuk memperoleh komposisi butanol yang mendekati murni.

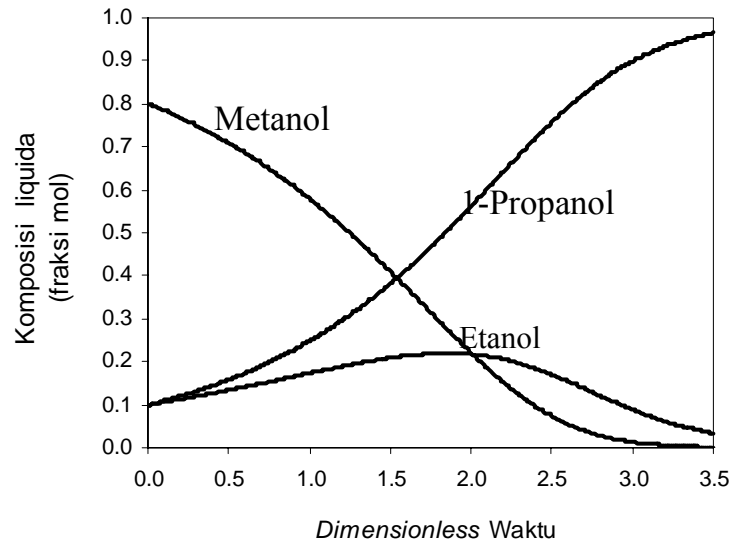

Gambar 9. Profil komposisi liquida MEP untuk Run-1.

Gambar 9 menunjukkan dimensionless waktu antara 0 sampai 1,5 dimana profil pergerakan komposisi metanol menurun, sedangkan etanol dan 1propanol pergerakan naik. Slope komposisi metanol lebih besar dibandingkan komposisi 1-propanol, karena komponen volatile (metanol) diuapkan dalam porsi yang lebih besar. Untuk dimensionless waktu antara 1,5 sampai 2 profil komposisi etanol konstan, karena temperatur MEP mendekati titik didih etanol sehingga komposisi etanol konstan. Untuk dimensionless waktu antara 2 sampai 3,5 komposisi etanol turun, karena temperatur MEP diatas titik didih etanol, sehingga komposisi etanol menguap dalam porsi kecil. Saat dimensionless waktu sama dengan 3 semua komponen volatile menguap dan saat dimensionless waktu sama dengan 3,5 temperatur ABE mendekati titik didih 1-propanol dan komposisinya mendekati murni.

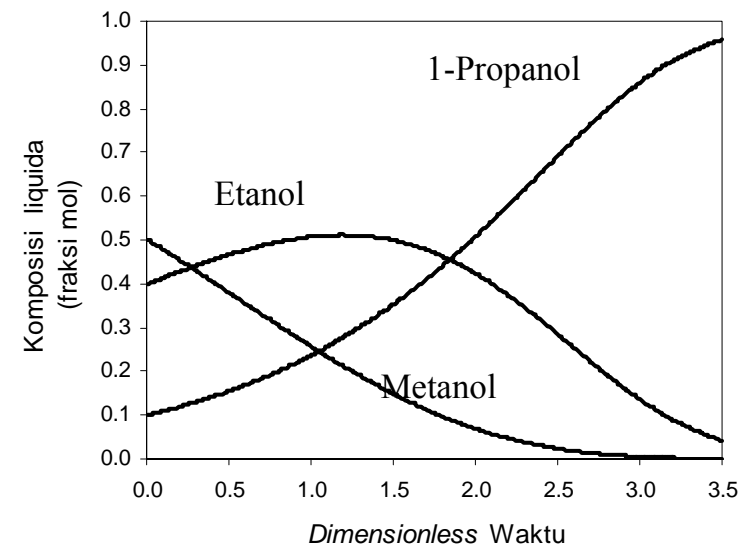

Gambar 10. Profil komposisi liquida MEP, run-6.

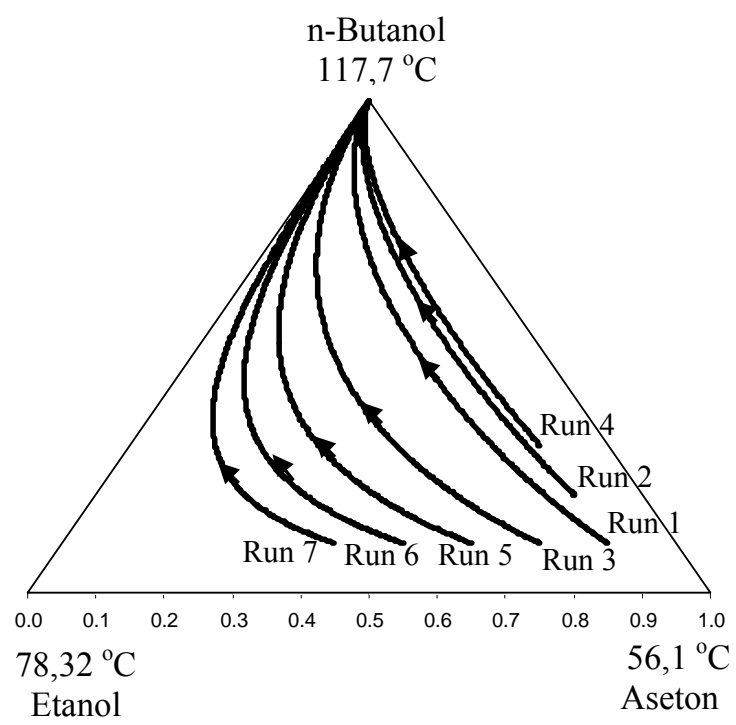

Gambar 11. Peta kurva residu ABE, Run-1 sampai Run-7

Gambar 10 menunjukkan bahwa dengan memperbesar komposisi etanol pada umpan masuk, maka temperature MEP lebih cepat mendekati titik didih etanol yaitu pada dimensionless waktu menunjukkan 1 sampai 1,5 . Hal yang sama juga untuk komponen metanol dimana pada saat dimensionless waktu menunjukkan 2,75 semua metanol sudah menjadi produk distilat. Untuk komponen 1-propanol menunjukkan hasil yang sebaliknya, pada saat dimensionless waktu menunjukkan 3,5 maka komposisi 1-propanol menunjukkan nilai 0,96 ; sehingga dibutuhkan dimensionless waktu yang lebih besar untuk memperoleh komposisi 1-propanol mendekati murni. Sehingga untuk memperoleh profil pergerakan komposisi etanol besar maka dilakukan memperbesar 
komposisi etanol pada umpan masuk, karena dalam distilasi batch sederhana hold-up diabaikan dan tanpa refluks ratio, dimana hold-up dan refluks ratio dapat memperbesar profil komposisi intermediate (etanol).

Gambar 11 menunjukkan peta kurva residu ABE dari Run-1 sampai Run-7, bergerak dari komponen light key (aseton), kemudian ke komponen intermediate key (etanol) terus menuju ke komponen heavy key (butanol). Untuk variasi komposisi umpan menunjukkan bahwa ABE setelah dilakukan simulasi distilasi batch sederhana membentuk campuran zeotropik tanpa membentuk biner azeotropik dari masing-masing komponen. Makin besar komposisi etanol pada umpan masuk maka peta kurva residu untuk komposisi etanol makin besar dan profil makin melengkung, sedangkan makin besar komposisi butanol pada umpan masuk maka peta kurva residu untuk komposisi etanol makin kecil dan profil menunjukkan garis lurus.

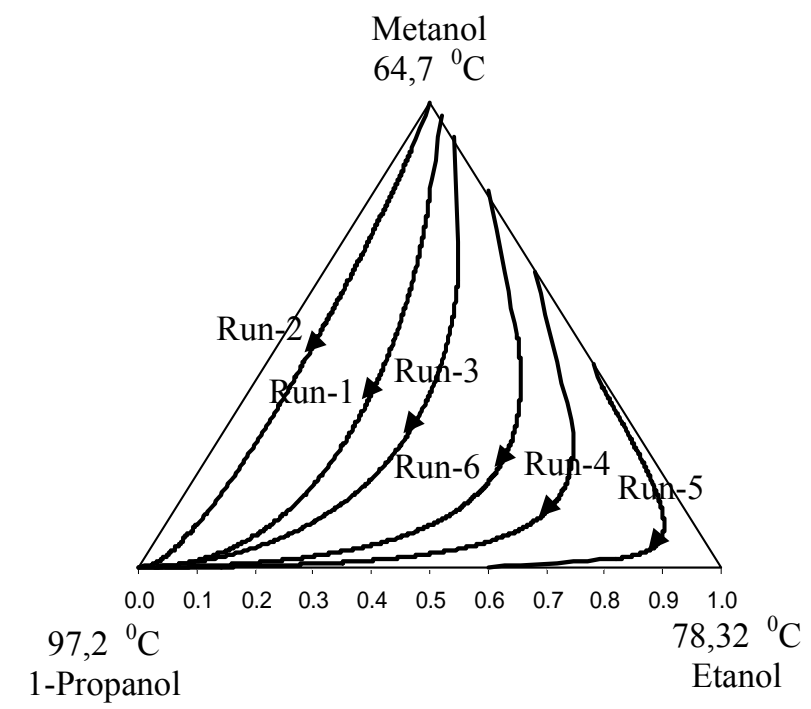

Gambar 12. Peta kurva residu campuran MEP, run-1 sampai run-6.

Gambar 12 menunjukkan peta kurva residu MEP dari run-1 sampai run-6, bergerak dari komponen light key (metanol), kemudian ke komponen intermediate key (etanol) terus menuju ke komponen heavy key (1propanol). Dari peta kurva residu untuk variasi komposisi umpan menunjukkan bahwa campuran MEP setelah dilakukan simulasi distilasi batch sederhana membentuk campuran zeotropik tanpa membentuk biner azeotropik dari masing-masing komponen. Makin besar komposisi etanol pada umpan masuk maka kurva residu untuk komposisi etanol makin besar dan profil makin melengkung, sedangkan makin besar komposisi 1-propanol pada umpan masuk maka kurva residu untuk komposisi etanol makin kecil dan profil pergerakan menunjukkan garis lurus.

Berdasarkan penelitian yang telah dilakukan, kalau dilihat dari peta kurva residu untuk campuran aseton-metanol membentuk campuran azeotropik, sedangkan kalau dilihat dari peta kurva residu untuk campuran aseton-etanol membentuk campuran zeotropik, maka berdasarkan penelitian yang telah dilakukan dapat diprediksikan bahwa untuk campuran aseton dengan senyawa gugus alkohol yang mempunyai rantai $\mathrm{C}$ (karbon) makin panjang seperti 1-propanol akan membentuk campuran zeotropik.

Dari Gambar 12 secara hubungan topologi kemudian dilakukan validasi hasil simulasi, berdasarkan pola aliran komposisi yang dibentuk dari masing-masing komponen, maka diperoleh $\mathrm{N}_{1}=2$ membentuk noda stabil untuk 1-propanol dan noda tidak stabil untuk metanol, $\mathrm{S}_{1}=1$ membentuk sadel untuk etanol. $\mathrm{N}_{2}=0$ karena tidak ada noda biner azeotropik, $\mathrm{S}_{2}=0$ karena tidak ada sadel biner azeotropik. $\mathrm{N}_{3}=0$ karena tidak ada noda terner azeotropik, $\mathrm{S}_{3}=0$ karena tidak ada sadel terner azeotropik, $\mathrm{B}=0$ karena tidak ada biner azeotropik. Setelah nilai yang diperoleh dari hasil hubungan secara topologi, kemudian dimasukkan dalam persamaan (14) sampai (17). Hasil yang diperoleh semua terpenuhi, sehingga simulasi distilasi batch sederhana setelah dilakukan validasi secara hubungan topologi memenuhi syarat.

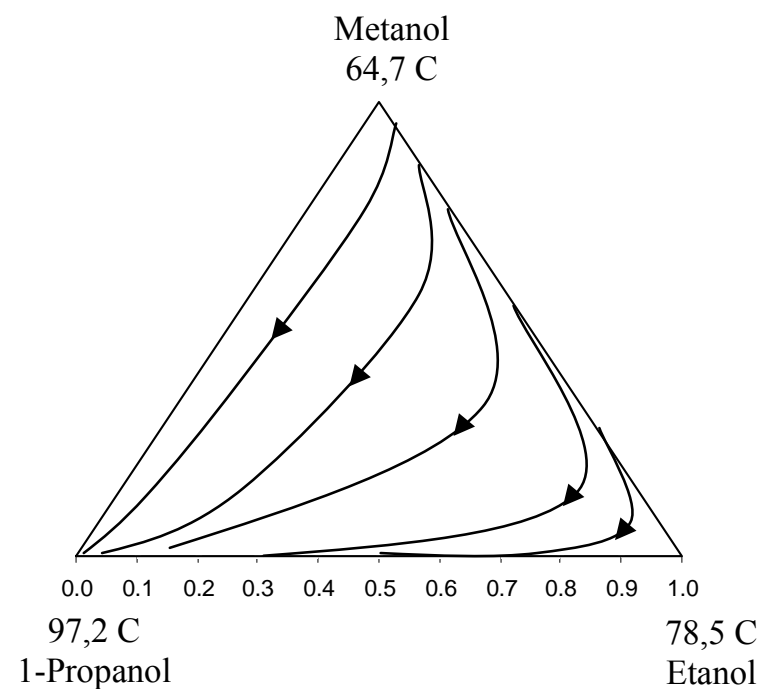

Gambar 13. Peta kurva residu campuran MEP, Henley dan Seader (1998).

Dilihat dari peta kurva residu sistem terner MEP pada Gambar 12, kemudian dilakukan validasi dengan literatur (Henley dan Seader, 1998) seperti Gambar 13. Dari hasil validasi menunjukkan profil peta kurva residu yang sama, antara peta kurva residu sistem terner MEP dari hasil listing simulasi sistem terner ABE (Gambar 12) dengan hasil literatur (Gambar $13)$.

\section{Kesimpulan}

Profil pergerakan temperatur campuran ABE dan campuran MEP dipengaruhi komposisi umpan masuk. Dilihat dari profil pergerakan komposisi 
liquida masing-masing komponen campuran $\mathrm{ABE}$ dan campuran MEP untuk Run-1, baik digunakan untuk memperoleh komposisi n-butanol murni dan 1-propanol murni dengan dimensionless waktu yang kecil. Untuk profil pergerakan komposisi liquida masing-masing komponen campuran ABE untuk Run-7 dan campuran MEP untuk Run-6, baik digunakan untuk memperoleh komposisi etanol murni dengan dimensionless waktu yang kecil. Dilihat dari peta kurva residu bahwa campuran terner ABE dan MEP membentuk campuran zeotropik tanpa membentuk biner azeotropik dari masing-masing komponen. Validasi secara hubungan topologi untuk simulasi distilasi batch sederhana campuran MEP memenuhi syarat. Validasi dengan literatur menunjukkan profil peta kurva residu yang sama.

\section{Ucapan Terima Kasih}

Peneliti mengucapkan terima kasih kepada Direktur Pembinaan Penelitian dan Pengabdian Masyarakat Direktorat Jenderal Pendidikan Tinggi, yang telah mendanai penelitian kami pada Hibah Pascasarjana nomor kontrak: 130/P21PT/DPPM/HTTP/IV/2004.

\section{Daftar Notasi}

\begin{tabular}{|c|c|}
\hline A & : aseton \\
\hline A & : parameter Antoine, Bar \\
\hline B & : n-butanol \\
\hline B & : parameter Antoine, Bar \\
\hline $\mathrm{C}$ & : parameter Antoine, Bar \\
\hline $\mathrm{D}$ & : distilat, $\mathrm{mol} \mathrm{s}^{-1}$ \\
\hline $\mathrm{d}$ & : diferensial \\
\hline $\mathrm{E}$ & : etanol \\
\hline K & : konstanta kesetimbangan \\
\hline M & : metanol \\
\hline $\mathrm{P}$ & : 1-propanol \\
\hline $\mathrm{P}$ & : tekanan, Bar \\
\hline q & : volume parameter UNIQUAC \\
\hline $\mathrm{r}$ & : luasan parameter UNIQUAC \\
\hline $\mathrm{t}$ & : waktu, s \\
\hline $\mathrm{u}_{\mathrm{ji}}$ & : parameter interaksi biner UNIQUAC, $\mathrm{J} \mathrm{mol}^{-1}$ \\
\hline $\mathrm{u}_{\mathrm{ji}}$ & : parameter interaksi biner UNIQUAC, $\mathrm{J} \mathrm{mol}^{-1}$ \\
\hline $\mathrm{v}$ & : kecepatan aliran uap, mol s$^{-1}$ \\
\hline $\mathrm{w}$ & : kecepatan aliran liquida, $\mathrm{mol} \mathrm{s}^{-1}$ \\
\hline $\mathrm{x}$ & : komposisi liquida, fraksi mol \\
\hline y & : komposisi uap, fraksi mol \\
\hline \multicolumn{2}{|c|}{ Huruf Yunani } \\
\hline$\gamma$ & : koefisien aktivitas \\
\hline & : dimensionless waktu \\
\hline \multicolumn{2}{|c|}{ Superscripts } \\
\hline Sat & : liquida jenuh \\
\hline \multicolumn{2}{|c|}{ Subscripts } \\
\hline B & : boiler \\
\hline $\mathrm{C}$ & : kondensat \\
\hline $\mathrm{D}$ & : distilat \\
\hline
\end{tabular}

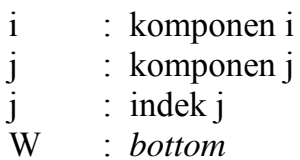

\section{Daftar Pustaka}

Doherty, M. F. and J. D. Perkins, (1978), "On the Dynamics of Distillation Processes: II. The Simple Distillation of Model Solutions", Chem. Eng. Sci., 33, pp. 281-301.

Doherty, M. F. and J. D. Perkins, (1979), “On the Dynamics of Distillation Processes: III. Topological Structure of Ternary Residue-Curve Maps", Chem. Eng. Sci., 34, pp. 1401.

Egbewatt, N. E. and J. Fletcher (2003), "Exploring Azeotropes in A Ternary Mixture", Science and Engineering Series, 4, No. 1, pp. 96-103.

Espinosa, J. and Enrique Salomone (1999), "Minimum Reflux for Batch Distillation of Ideal and Nonideal Mixtures at Constant Reflux", Ind. Eng. Chem. Res., 38, pp. 2732-2746.

Gmehling, J. and U. Onken, (1977), "Vapor-Liquid Equilibrium Data Collection", DECHEMA Chemistry Data Series, I, DECHEMA, Frankfurt.

Henley, E. J. and J. D. Seader, (1998), “Separation Process Principles”, pp. 586-712, John Wiley \& Sons, Inc., New York.

Prausnitz, J. M., (2001), “The Properties of Gases and Liquids”, ed. 5, pp. A.50 - A. 51, Mc. GrawHill, New York.

Rayleigh L., (1902), Phil. Mag. [vi.], No. 4 (23), pp. 521.

Soemantri, Widagdo and Warren D. Seader, (1996), "Journal Review Azeotropes Distillation", AIChE J., 42, No.1, pp. 96-130.

Stichlmair, J., J.R. Fair, and J.L. Bravo, (1989), Chem. Eng. Progress, 85 (1), pp. 63-69.

Villiers, W. E. DE., et al., (2002), “Navigate Phase Equilibria via Residue Curve Maps", Chemical Engineering Progress, pp. 66-71. 